\title{
Oor die bestaan van God en oor niksheid
}

Kobus Labuschagne

Tydelik-deeltydse dosent Departement Kerkgeskiedenis (Afd A)

Universiteit van Pretoria

\begin{abstract}
On the existence of God and on nothingness

The views of Karl Barth and the 'Heilsgeschichte'-tradition on the one hand, and those of Rudolf Bultmann and the 'Formkritik'-tradition on the other hand, do not differ so much on the method of objective historical research. The real differences start to appear on the hermeneutical front, where facts and events referred to in the Scriptures are evaluated and explained. The 'Heilsgeschichte'-tradition is consistent in maintaining an objective point of departure, whilst Bultmann and the 'Formkritik'-tradition, influenced by existentialist philosophy, reveals a subjective approach. For Bultmann the kerygma cannot be verified historically but only subjectively or existentially. For Barth the kerygma cannot be separated from its true basis of historical events, in and through the person of Jesus Christ. These two different approaches have enormous consequences for the question of the existence of God.
\end{abstract}

\section{INLEIDING}

'n Mens lewe nie slegs in homself gekeer nie, maar in 'n bewustelike relasie met die wêreld rondom hom. Deur sy verstandsfunksies se vertolking van wat die mens waarneem en belewe van die wêreld van dinge en objekte rondom hom, kom die mens tot wat hy beskou as kennis van sy wêreld. Mense dink in skemas. Selfs om dit te ontken, is maar net 'n nuwe skema. Van die kennisproses het die mens gaandeweg 'n wetenskap gemaak, om hom daarmee duidelik en noukeurig en grondig te probeer

* 'n Verhandeling oor die empiriese geskiedenisbeskouing, met verwysing na sy ontwikkeling in die teologiese konteks van die $19 \mathrm{e}$ en $20 \mathrm{e}$ eeu, en na sy toepassing op die opstanding van Jesus Christus. Referaat gelewer tydens 'n simposium van teoloë en filosowe, aan die Universiteit van Pretoria, 15 Augustus 1996, georganiseer deur die Sentrum vir Teologiese Navorsing en Toerusting, Fakulteit Teologie (Afd A). 
verantwoord ten opsigte van die metodiek waarvolgens uiteindelik die aanspraak gemaak word op feite en ware kennis. Wetenskaplike kennis oortuig ook uit sy resultate van wat daaruit verklaar word van die werklikheid, en van wat daaruit geskep word in tegnologie en verbruikersmiddele. So word strenggesproke alleen daardie feite wat deur wetenskaplike metodiek noukeurig bepaal is en ondersteun word, as ware kennis aanvaar - daarbuite is daar nie sprake van wetenskaplike kennis, of ware kennis nie, maar alleen moontlikhede, veronderstellings, menings, en hipoteses. Vasstellings van feite, vir breë algemene aanvaarding, word dikwels gekompliseer deur verskillende insigte van navorsers, maar dit wat sy resultate kan toon in wat prakties werk, kan moeilik weerlê word. Wanneer die wetenskaplike metodiek sekere dinge vir feite en werklikheid vasstel, wil dit egter nie sê dat alleen daardie wêreld bestaan en alles daarbuite nie bestaan nie. Dit sou juis 'n onwetenskaplike uitspraak wees; die wetenskap kan nie sê of iets bestaan of nie bestaan wanneer die wetenskap nog nie feite of mate van duidelikheid daaroor kon vasstel nie. So beweeg die wetenskaplike soeke tussen werklikheid (van wat reeds vasgestel kon word) en niksheid (ten opsigte van dit waaroor ons niks of nog niks weet nie). Niksheid sê dus nie dat daar ' $n$ afwesigheid van ' $n$ werklikheid is nie, maar alleen dat ons tans niks daarvan weet en beweeg binne 'n ruimte van niksheid. Ook in ons vrae en soeke na God bevind die wetenskaplike metodiek hom dikwels, in beperkte vermoëns, dobberend tussen werklikheid en niksheid. Nooit kom ons los van die waarheid van die apostel Paulus se uitspraak: 'Ons ken ten dele' (1 Kor 13:12). Ons weet nie alles van alles af nie, ons wete bly op hierdie wêreld beperk en onvoltooid. Dit moet ons egter nie laat terugdeins van ons uitdaging nie.

\subsection{Historiese agtergrond}

Waar die middeleeuse mens deurgaans gerig was op 'n ander wêreld as hierdie wêreld, onder voorskrif en leiding van die kerk, het die renaissance wat gevolg het, die aandag gevestig op die wêreld van nou en hier en op 'n mens buite die gesagsfeer van die kerk. Hierdie nuwe wêreld wat met die renaissance-gees aan die opkom was, met sy nuwe geleerdheid, het gaandeweg gelei na 'n empiriese wetenskapsleer of, ánders gesê, 'n objektiewe wetenskap wat daarop ingestel was om die natuur te ken en om dit uiteindelik deur tegnologie diensbaar te maak aan die mens.

Die eerste stadium van die ontwikkeling van 'n empiriese wetenskapsbeskouing maak sy verskyning in die $17 \mathrm{de}$ eeu, met die jaar 1687 as hoogtepunt wanneer Isaac Newton (1643-1727) se Principia Mathematica verskyn. Daarmee saam het die emansipasie van die natuurwetenskappe plaasgevind, wat nou op hulle eie reg as onafhanklike empiriese dissiplines begin funksioneer het. 
Die tweede stadium vind in die 19de eeu plaas wanneer die empiriese wetenskapsmetode nou ook op die mens van toepassing gemaak word, en nou volg die emansipasie van die historiese wetenskap en die res van die menswetenskappe (geesteswetenskappe). Uiteindelik word self die teologiese wetenskappe nie onaangeroer gelaat nie.

Afgesien van Newton, moet veral die naam van Immanuel Kant (1724-1804) vermeld word vanweë sy groot bydrae in die fondamentlegging van 'n nuwe wetenskapsleer. In die voorrede tot die eerste oplaag van sy Kritik der Reinen Vernunft (Kritiek van die Suiwere Rede) van 1781 stel Kant die doel van sy werk: 'Ek verstaan hieronder egter nie 'n kritiek oor boeke en sisteme nie, maar 'n kritiek oor juis die vermoëns van die rede, ten opsigte van alle kennis, of dit daarna mag strewe onafhanklik van alle ervaring ...' (Kant 1956:7, 8; my vertaling). Vir Kant het alle tradisionele metafisika, wat op die veronderstelling van aprioriese kennis berus, tot ' $n$ einde gekom. Die groot blywende waardevolle van Kant, tot vandag toe, volg uit sy analise van ons ervaringskennis - ervaringskennis as wetenskaplik geleide verwerking van dit wat ons sintuie waarneem en ons bewussynsfunksies maak van die objekte waarmee hulle in aanraking kom. Kant leer dat in die ervaringskennis ons nie ons vertrekpunt mag neem in bloot die veronderstellings van die menslike bewussyn nie - dit het geen aanspraak op kennis nie - maar ons kan alleen ons vertrekpunt neem in 'n sintuiglikwaarneembare objek, wat selfstandig buite ons bewussyn staan. Vanuit hierdie belangrike stellinginname ontwikkel die empiriese wetenskapsbeskouing, of dan die objektiewe wetenskap.

Tog het Kant se filosofie dualisties gebly - in aansluiting by die eeue-oue Platoniese dualisme. Vir Kant was die mens burger van twee wêrelde:

* In sy sinlike natuur is die mens heteronoom, dit wil sê onderworpe aan wette van buite, van die natuur. Dan sê hy daar bestaan nie iets soos aprioriese kennis nie. In aansluiting hierby en by sy beskouings (soos uitgewerk in sy 'Kritiek van die Suiwere Rede') ontwikkel - afgesien van 'n objektiewe wetenskap - ook uiterste beskouings soos positivisme, materialisme en biologisme.

* As bo-sinlike wese is die mens outonoom. Dan kan Kant onbewysbare postulate aanvaar: God, vryheid en onsterflikheid. En nou is die klem op die vryskeppende aktiwiteite van die bewussyn. In aansluiting hierby ontwikkel weer die romantiek (as denkklimaat) en hieruit die sisteme van die Duitse idealisme (van Fichte, Schelling en Hegel), en later volg ook die eksistensialisme (Heidegger, Sartre ens). 
Hierdie dualisme het ook die teologiese denkwêreld beïnvloed: met of die uitgangspunt in die outonome empiriese werklikheid buite die menslike subjek, of met die uitgangspunt die vry-skeppende menslike subjek self.

Edmund Husserl (1859-1938), een van die invloedryke filosowe van die 20e eeu, sou later opmerk, en talle is dit met hom eens, dat alleen Kant se 'Kritiek van die Suiwere Rede' 'n toekoms vir ons denke gehad het, en dat sy latere twee kritieke (Kritik der praktischen Vernunft en Kritik der Urteilskraft - wat albei uitdrukking gee aan die 'praktiese rede' en die vry-skeppende aktiwiteite van die menslike bewussyn) eintlik 'n terugval in die metafisiese opvattings wat hy reeds oorwin het in sy eerste 'Kritik', beteken het (Kuypers 1966:133).

Hoewel die wêrelddenke hedendaags radikale post-moderne elemente vertoon, wat hom geensins wil verbind aan bane en grense nie, skerp onderskeidings en verskille probeer oorskry, en eweneens strewe na 'n soort sosiale konsensus, moet nogtans gesê word dat in harde werklike feite ons wetenskapsbeskouing beslissend en oorwegend empiries bly en is ons kultuur (volgens ' $n$ jonger-geslag teoloog) '... a culture determined by a tradition where the sciences - especially the natural sciences - not only dominate the way we live our lives, but ultimately function as the paradigm and apex of human rationality' (Van Huyssteen 1996:105).

Die empiriese wetenskapsbeskouing is, gekwalifiseerd, steeds die beste beskikbare metode vir wetenskaplike navorsing en die beste voorbeeld van menslike rasionaliteit aan die werk (Van Huyssteen 1996:126). Die empiriese metode is uniek vanweë sy 'history of success in coping with the problems of empirical reality' (Van Huyssteen 1996:127), of sterker en duideliker gestel: vanweë sy enorme vooruitgang in middele (dink bv aan medisyne) en tegnologie (motors, vliegtuie, allerhande soorte apparate wat die mens se lewenskwaliteit verbeter). Aprioriese kennis het na die opkoms van die empiriese wetenskapsbeskouing eens en vir altyd 'n saak van onmoontlikheid geword.

\section{DIE EMPIRIESE WETENSKAPSBESKOUING}

\subsection{Basiese uitgangspunte van die Empiriese Wetenskapsbeskouing}

Afgesien van die kwalifisering en modifisering wat sal voortspruit uit die historiese wetenskap se verskillende objektewêreld, bly die empiries-historiese wetenskap nogtans deel van 'n breë-algemene empiriese wetenskapsbeskouing. Soortgelyk is dit dus ook by die ander menswetenskappe. En selfs van die teologie kan gesê.word: '... theology and science do share common resources of rationality' (Van Huyssteen 1996:125).

\subsubsection{Die wetenskap strewe na kennis}

Wetenskaplike kennis is die resultaat van noukeurige objektiewe sintuiglike waarneming (met behulp van watter tegnologiese instrumente van ons tyd nou ook al) en die 
rasionele ontleding en verwerking daarvan deur 'n denk-aktiewe menslike subjek (met behulp van watter moderne tegnologie nou ook al - soos rekenaars byvoorbeeld). Kennis bestaan in ' $n$ relasie tussen 'n subjek (menslike bewussyn) wat ken en 'n objek (wat soos Rescher dit noem: 'mind-independent' is) wat geken word (Van Huyssteen 1996:122).

\subsubsection{Wetenskaplike kennis staan basies op drie bene: objektiwiteit, algemeen- geldigheid en noodwendigheid (vgl De Vleeschauwer 1952:133-215)}

Objektiwiteit: Die vertrekpunt en laaste grond van die empiriese wetenskapsbeskouing is 'n self-standige ('mind-independent') objek buite die bewussyn van die mens wat navorsing doen. 'n Aprioriese vertrekpunt, los van 'n objektiewe werklikheid, wat bloot sy ontstaan te danke het aan die voorstellings van die vry-skeppende menslike bewussyn, kan uiteraard nie aan 'n selfstandige werklikheid gekontroleer word nie, en kan daarom nie op wetenskaplike kennis aanspraak maak nie. H Brown sê: ' $\ldots$ one of the most important features of science is precisely its systematic pursuit of objective evidence' (Van Huyssteen 1996:120). Vanweë die noodsaaklike vertrekpunt in die historiese objektiewe gegewene sê Karl Barth dan van die bestaan van Jesus Christus: 'Sy bestaan kan nie apriories afgelei en gepostuleer word nie; dit kan en moet na die feit verstaan word' (Barth 1964:50; my vertaling).

Algemeengeldigheid: 'n Wetenskaplike feit is dit wat onder dieselfde voorwaardes deur enige ingeligte waargeneem kan word om tot dieselfde konklusie te kom - dan het ons algemeengeldigheid. Die waarneming en beoordeling wat gemaak word, moet vir elke normale verstand toeganklik, vatbaar en aanneemlik wees.

Noodwendigheid: Dit is wanneer oor en oor vasgestel word dat geen ander waarneming en beoordeling noodwendig gemaak kan word nie. Daar kan onderskei word tussen volstrekte en betreklike noodwendigheid (noodsaaklikheid). 'n Kennisoordeel is volstrek wanneer daar geen uitsonderings kan wees nie, en dit is betreklik wanneer daar 'n voorwaarde of voorwaardes bestaan alvorens ' $n$ feit as noodwendig waar aanvaar kan word.

\subsubsection{Waarheid en sekerheid}

Om wetenskaplik te kan ken, beteken altyd om te kan oordeel of iets waar en seker is. Die logiese waarde van kennis word gemeet aan waarheid. Sekerheid verskyn aan ons 
in die sin van 'n logiese dwang om met die kennisbeoordeling in te stem. Die waar heids- en sekerheidskriterium is evidensie. Evidensie wil sê dat die betrekking wat 'n kennisooreel (in die navorsing van 'n objek) met sy logiese gronde het, so oortuigend en afdwingend inwerk op ons verstandelike insig dat ons nie anders kan nie as om die kennisoordeel vir waar en seker te hou.

\subsubsection{Interpretasie van die ervaringsobjek}

Anders as voorheen, weet ons hedendaags dat ons sintuiglike vermoëns en bewussynswerkinge (met of sonder ons moderne gesofistikeerde tegniese apparaat) nie in staat is tot 'n onmiddellike of direkte kontak met die kennisobjek, om die werklikheid $100 \%$ suiwer weer te kan gee nie. Eienskappe wat byvoorbeeld deur ons sintuie waargeneem word (kleur, klank, smaak ens) is slegs ' $n$ menslike weergawe of vertaling van die werklikheid. Nicholas Rescher praat van wetenskaplike kennis as interpretasie van die ervaringsobjek (Van Huyssteen 1996:122). Sintuie en verstandsfunksies het dus nie 'n direkte kontak met ' $n$ objek van ondersoek nie, en dit dra dus nie die werklikheid bloot oor nie. Die verstand verwerk in die menslike bewussyn dit wat waargeneem word, tot bepaalde kennisoordele (of wetenskaplike feite). Met die vertrekpunt in die objektiewe werklikheid self, kom ons nogtans nie geheel los van 'n menslik-sub-jektiewe bydrae nie. Ons het nog geen absolute bewys kon vind dat die objektiewe werklikheid presies dit is wat ons in ons ervaringskennis weergee nie. Wetenskaplike kennis is egter onmoontlik sonder 'n ooreenkomstigheid van ons denkoordele met die objek van waarneming (De Vleeschauwer 1952:199). Die bewyskrag lê egter in die sigbare vooruitgang van die empiriese wetenskapsbeskouing en die praktiese suksesse daarvan in sy tegnologie (wat prakties werk en prakties bruikbaar is). Nicholas Rescher beklemtoon dat dit " $n$ wonder' is dat die menslike bewussyn in staat is om iets van die wêreld, van die natuur, 'n objek, te kan waarneem deur die oog se fisiologiese vermoëns en te kan verstaan deur sy intellektuele vermoëns (Van Huyssteen 1996:121).

\subsubsection{Ervaringskennis}

Waarvan ons in die empiriese wetenskapsbeskouing moet praat, is ervaringskennis. Ervaringskennis is die wetenskaplik geleide verwerking van dit wat ons sintuie en bewussynsfunksies maak van voorwerpe (objekte) wat nagevors word. Hierdie objekte het 'n selfstandige bestaan buite die bewussyn van die navorser.

\subsubsection{Veranderlikheid}

Tog is daar ook ontwikkeling en aanpassings, dus verandering, in die metodiek van die objektiewe wetenskap. Wat konsekwent dieselfde bly, is die objektiewe vertrekpunt, en objektiwiteit as laaste grond. Die objektiewe wetenskap is nie uitverkoop aan sy 
tradisionele basiese uitgangspunte nie, maar ontwikkel dit en pas dit aan. Ons moet aanvaar dat daar ontwikkeling plaasvind ten opsigte van ons wyses van sintuiglike waarneming (bv deur instrumente) en ook ten opsigte van ons kriteria van rasionaliteit - namate ons wetenskaplikheid in praktyk self ontwikkel. Ons poog immers altyd om so na as moontlik aan waarheid en werklikheid te kom. Ons kennis is gevolglik ook nie iets wat stilstaan nie; dis altyd in ' $n$ proses van wording - ons ontdek altyd nuwe dinge en daarmee saam word ons kennis aangepas. Vir die wetenskapsleer geld dit: Waarheid en werklikheid IS nooit nie, maar dit WORD, dit is dus in beweging. Ons kan nie stagneer in ' $n$ fundamentalisme wat totaal onbuigsaam is nie. Wetenskaplike kennis kan nooit volledig of perfek wees nie. Die openheid ten opsigte van nuwe benaderings wil egter nie sê dat ons nie ook moet waak teen sommige aspekte van die hedendaagse post-moderne siening wat dreig om in 'n relativisme te verval nie. Die ou uitgangspunte moet daarom nie bloot in totaal verwerp word nie, maar dit moet steeds aangepas en ontwikkel word, en daar moet steeds nuwes daarop voortgebou word. Nuwe uitgangspunte moet egter getoets word vir hulle wetenskaplike houdbaarheid. Tog beklemtoon ons: Objektiewe prosedures voorsien steeds die beste en betroubaarste bewyse en getuienis in ons soek na kennis (vgl Van Huyssteen 1996:118121). Brown voorsien die volgende aanvullende prosedures vanuit 'n post-moderne benadering wat oorweeg behoort te word (Van Huyssteen 1996:114,115):

* In die klassieke model van die empiriese wetenskapsbeskouing word die klem gelê op die logiese relasie (hoe daar tot kennis gekom is) tussen die objek en die subjek (menslike bewussyn). En dan word die objektiewe getuienis beklemtoon wat gelei het tot ' $n$ bepaalde kennisoordeel (wetenskaplike feit). Die nuwe benadering wil dit behou en byvoeg: dat die mens as 'rasionele agent' wat die navorsing doen, ook 'n basiese uitgangspunt word. Die rol van die agent moet meer aandag ontvang die rasionele wyse waarop hy of sy objektiewe getuienis hanteer om tot 'n slotsom te kom, verdien dan meer aandag.

* Die vermoë moet gevind word om te oordeel in 'n moeilike situasie waar ons nie behoorlike reëls het om ons te lei tot beslissings nie. Beoordeling staan sentraal in hierdie 'model van rasionaliteit'. Kundige advies moet minstens gesoek word waar daar tekortkominge is.

* Die derde stap van Brown se alternatiewe beskouing is die invoering van 'n 'sosiale element'. Hiervolgens moet 'rasionele beoordeling sosiaal bemiddel 
word', eerder as om deur 'n proses van reëls gelei te word. 'n Rasionele oordeel moet voorgelê word vir instemming aan 'n gemeenskap van navorsers wat deel in die relevante kundigheid. (Die gedagte van algemeengeldigheid word hier verder uitgewerk.)

\subsubsection{Waarskynlikheid}

Waarskynlikheid is die groot faktor in die moderne kwantum-fisika. Die kwantumteorie word bevestig en ondersteun in groot massas van eksperimentele gegewens, en moet beskou word as een van die grootste intellektuele oorwinnings van die fisika in die geheel (Bullock \& Stallybrass 1977:517, 518). Die navorsingswerk van Heisenberg, Pauli, Born, Bohr, Dirac, Schrödinger en veral Einstein kan in hierdie verband genoem word. Wat is nou die gevolg van die kwantum-teorie vir die strenge natuurwetmatigheid waaraan die fisici vanaf Newton tot Einstein gewoond geraak het? Van absolute gedetermineerdheid in die natuur moet empiries-wetenskaplik afgesien word. Daar moet bykomend tot werklike wetmatigheid ook rekening gehou word met 'waarskynlikheid' (Bernstein 1976:142), en hiervan kan die objektiewe wetenskap hom nie losmaak nie.

\subsection{Die empiriese geskiedenisbeskouing met besondere verwysing na die historiese} konteks van die teologiese wetenskappe (19e en 20e eeu)

Teologiese studie is onlosmaaklik verbind aan dinge wat in die verlede plaasgevind het, en so is teologiese studie verbind aan die empiries-historiese wetenskap. Alan Richardson sê: 'To put it more simply, the Church is what it is because of certain things which have happened in the past.' En:

Hence theological study is inevitably committed to the study of history, and historical theology is the scientific basis of all theological study. Historical theology asks what actually happened in the past, and it employs all the resources which modern scientific historical method places at the disposal of scholarship.

(Richardson 1956:49)

In aansluiting by dit wat hierbo by 2.1 gesê is, lei die praktyk die empiries-historiese wetenskap na sy eie kwalifisering en modifisering van die basiese uitgangspunte van 'n empiriese wetenskap. 
Die vertrekpunt en laaste grond van 'n empiriese geskiedenisbeskouing - ook in die teologiese navorsing van die verlede - bly in die objektiewe werklikheid buite die menslike subjek. Daar word dus gestrewe na geobjektiveerde kennis - op basis van getuienis of dokumentasie oor gebeure wat noukeurig aan herhaalbare ondersoek (algemeengeldigheid) blootgestel word, en waaruit ons dan tot noodwendige konklusies kom. In daardie sin word aanspraak gemaak op ware en sekere kennis, wat logiesverstandelik tot ons spreek uit die evidensie van die kennisoordeel.

Vanuit die teologie, kan gesê word: Sekerheid geld by geobjektiveerde kennis, maar oortuiging volg uit 'n subjektiewe gewaarwording. Geobjektiveerde kennis lewer vir seker 'n groot bydrae, maar dit is uiteindelik die oortuiging van 'n persoonlike of eksistensiële belewing, op grond van daardie kennis, waardeur ek subjektief tot 'n geloofsuitspraak kom om Jesus te bely as my Here en my God. Die wêreld van geloof kan nie vasgevang word binne die grense van die objektiewe wetenskap nie; dit gaan dit te bowe, en ons kan daarom ook nie altyd alles daarvan verklaar nie. Wat betref die eksistensiële toe-eiening van die geloof lewer die eksistensiële teologie (bv van Rudolf Bultmann), in gekwalifiseerde sin, vir ons 'n waardevolle bydrae. Maar dit net ten dele; want dit was by uitstek die opkoms en ontwikkeling van die empiriese metode in die naturwetenskappe en vervolgens in die geskiedeniswetenskap wat die ware aard van die Bybel, as getuienis en beriggewing van God se openbaring in Christus in die geskiedenis, meer duidelik aan ons gemaak het as ooit tevore in die pre-wetenskaplike. tye. Vir die empiriese metode van ondersoek is dit noodsaaklik om die waarheid van die Bybel in objektiewe navorsing te bevestig. Subjektiewe willekeur is nie in staat tot wetenskaplike kennis nie, want dit kan nie gekontroleer word nie en dit is daarom nie betroubaar - waar en seker - nie. Dit neem nie weg nie dat daar dinge in die Bybel is wat, deur die oog van sy skrywers en getuies, wetenskaplik waargeneem kan word, maar nie wetenskaplik (bv deur middel van oorsaak en gevolg) verklaar kan word nie: Die wonders en die opstanding van Christus is voorbeelde hiervan. Maar hierdie dinge bly nogtans objektiewe werklikheid wat destyds aanskou is, en die moderne navorser kan dit nie net probeer weg verklaar soos dit hom pas nie.

Die empiriese metode het uiteindelik in die 20ste eeu, deur teoloë soos Karl Barth, Emil Brunner, Oscar Cullmann en vele andere, in die Heilsgeschichte-teologie sterk na vore getree. In die 'Heilsgeschichte'-teologie word 'n noue band getrek tussen die sekerheid van die geobjektiveerde kennis en die geloofsoortuiging van die subjektiewe of eksistensiële gewaarwording. Vir die 'Heilsgeschichte'-teologie is ons geloof egter afhanklik van die feit of die sentrale gebeure in Christus (bv van veral die opstanding) werklik plaasgevind het. Om te sê dat dit nie saak maak nie, vernietig die hele basis van ons geloof (vgl Richardson 1968:140). Heilsgeskiedenis-teologie hou vas aan die vertrekpunt en laaste grond in die objektiewe werklikheid van die geskiedenis. 
Van Niftrik: 'In die "objektiwiteite" vind ek die grond waarin my anker ewig vasgryp'. 'Hierdie Bybelse objektiwiteit dreig ons in ons tyd om te verloor, en daarmee saam die sekerheid en die blydskap, die troos en die uitsig van die geloof' (Van Niftrik 1971:109,110).

Brunner sê: 'Waarheid as ontmoeting ... wys na die God wat tot ons spreek in die Bybel, bo-alles, in die geskiedenis van Jesus Christus. Hierdie Christus is nie die Christus van die ortodoksie nie, ook nie die "historiese [historische] Jesus" van die liberalisme nie, maar die historiese [geschichtliche] Jesus, die Christus en die Verlosser van die Bybel se boodskap' (Brunner 1964:49; my vertaling). So beklemtoon Brunner die objektiewe vertrekpunt in die geskiedenis as die selfstandige en objektiewe werklikheid van die Christusgebeure wat nie sy oorsprong kan hê in ortodokse mensgemaakte rasionele dogmas nie en ook nie sy oorsprong kan hê in die subjektiewe van liberale menslike bewussynservaringe nie. [Wanneer Barth en Brunner, en andere, van die eiesoortigheid van die Christusgebeure praat, dan is dit vir hulle nie gewone historie nie - en die Bybel lewer ook nie ' $n$ historiese relaas in die gewone sin nie - maar dit is iets hoër as gewone historie. Dit is 'geschichtlich', geskiedenis op 'n hoër vlak, en daarom praat hulle van 'Heilsgeschichte'.]

Barth se in sy Kirchliche Dogmatiek: Die getuienis van die dissipels moet in die navorsing van die tekste van die Nuwe Testament gevind word, en daarmee saam moet begryp word dat die Nuwe Testament historiese dokumente is met hulle eie karakter (vgl Barth 1955:167). Barth lê groot klem op die historiese werklikheid as vertrekpunt, en so ook Cullmann.

Vir Oscar Cullmann was die hoogtepunt van die Nuwe-Testamentiese Christologie die belydenis dat Jesus God en Here is in sy selfopenbaring (vgl Cullmann 1963:326). Hy sê dan: '.. alle Christologie is heilsgeskiedenis, en alle heilsgeskiedenis is Christologie' (Cullmann 1963:326). En verder: '.. die vraag oor Jesus is nie deur die vroeë Christendom beantwoord in terme van 'n mitologie wat voor hande was nie, maar in terme van ' $n$ reeks van werklike feite' (Cullmann 1963:316). Cullmann beves tig dat hy en ander navorsers feite gevind het wat dui op die beïnloeding van NuweTestamentiese skrywers deur hulle Hellenistiese omgewing, maar die tekste dui nie op beinvloeding wanneer dit kom by die basiese boodskap van die verlossingsgeskiedenis nie. Die Christologie het sy oorsprong uit gebeure, die Heilsgeschichte, insluitende kruis en opstanding. Dit is nie mites van 'n nie-historiese kerugma nie (Cullmann 1963:316, 317).

Die 19e eeuse liberale teologie maak wel die fout om, onder druk van die historiese kritiek, die objektiewe historiese vertrekpunt prys te gee ten gunste van 'n subjektiewe vertrekpunt. Schleiermacher (1768-1834) se groot invloed in die $19 \mathrm{e}$ eeu kan 
moeilik oordryf word. Schleiermacher het 'n raamwerk gebied vir 'n histories-kritiese ondersoek van die Bybel en so dan twee rigtinggewende beskouings uitgewerk: (1) Die Christendom is 'n 'positiewe' historiese godsdiens - nie 'n universeel-rasionele godsdiens nie. Dis 'n spesifieke godsdiens met ' $n$ beginpunt in die geskiedenis, en dit bestaan vandag in die bewussyn van bepaalde mense. (2) Die locus van die openbaring van God is in die mens se religieuse bewussyn (Richardson 1968:80-84). Schleiermacher definieer godsdiens nie as kennis of as aktiwiteit nie, maar as gevoel en intuitsie. Hy sê: 'God word aan ons gegee in gevoel op 'n oorspronklike manier; en wanneer ons praat van 'n oorspronklike openbaring van God aan die mens of in die mens, dan sal die betekenis altyd net dit wees, dat, gepaardgaande met die absolute afhanklikheid wat nie alleen die mens nie maar alle tydelike bestaan karakteriseer, daar aan die mens ook die onmiddellike selfbewussyn gegee is van dit wat word tot 'n bewussyn van God' (Labuschagne 1987:264).

Op basis van Schleiermacher se denke was die algemene trant van die $19 \mathrm{e}$ eeuse liberale teologie sodanig dat dit die Christelike geloof beskou het as een of ander vorm van menslike selfbewussyn - waarop die klem nou ook geval het (Richardson 1968: 123). Vir die liberale teologie is die teologie van die vroeë kerk, soos weergegee in die Nuwe Testament, essensieel 'n toemaking van die eenvoudige boodskap van Jesus deur vreemde elemente van Joodse apokaliptiek en Hellenisties-Gnostiese mitologie wat verantwoordelik was vir 'n distorsie van die oorspronklike apostoliese kerugma. Deur die $19 \mathrm{e}$ eeu is algemeen gereken dat die Christelike godsdiens in die Bybel alleen verdedig kon word deur dit te interpreteer as uitdrukking van die godsdienstige ervaring van gelowiges. Geloof in die Bybel, en in ons lewe, is losgemaak van die historiese gebeure waarna die Skrif verwys. Strauss (1808-1874) - in sy Leben Jesu (1835- 6 ) redeneer dat die bonatuurlike elemente in die Evangelies mites was, sonder historiese begronding, wat ontstaan het in die lang tussenperiode tussen die dae van Jesus en die tyd toe die Evangelies geskrywe is.

Die liberale teologie - bv by Von Harnack - onderskei tussen die suiwer 'godsdiens van Jesus' en die 'godsdiens aangaande Jesus', waarmee Paulus en die Helleniseerders eersgenoemde oorskadu het (Richardson 1968:87). Die Vormkritiek van Rudolf Bultmann en andere, in die 20e eeu, bou voort op die historiese kritiek van die $19 \mathrm{e}$ eeuse liberale teologie, en beklemtoon die 'godsdiens aangaande Jesus'.

Beide beroemd en berug is Bultmann se uitspraak in 1948, naamlik dat mens nie elektriese lig en 'n radiostel kan gebruik, in geval van siekte 'n beroep kan doen op geneeskundige en kliniese middele, en tegelykertyd aan die geeste- en wonderwêreld van die Nuwe Testament kan glo nie (Van Nifirik 1971:74). 'n Uitspraak soos hierdie 
is 'n blote subjektiewe mening en kan nie aanspraak daarop maak om 'n wetenskaplike oordeel te wees nie, want 'n wetenskaplike oordeel word begrond op noukeurige empiriese waarneming. Bultmann wil die Bybel ontmitologiseer. Wat hy sien as mites in die Bybel, verklaar hy hermeneuties as uitdrukking van die Selbstverständnis (selfverstaan) van die mens (Van Niftrik 1971:44, 74, 76). Bultmann glo aan geen historiese opstanding van die Here Jesus nie, en vir hom het daar nie wonderwerke plaasgevind nie (Richardson 1968:106, 111). Bultmann gun aan die kerugma van Jesus Christus geen steunpunt in die natuur of die geskiedenis nie (Van Niftrik 1971:88). Hermeneuties is sy siening so te verduidelik:

Die siening van die Vormkritici is dat ons nie histories in staat is om agter die teologie van die Nuwe-Testamentiese kerk (Gemeindetheologie) - soos weergegee deur die Bybelskrywers - in te kom nie, en om so enige betroubare kennis van die lewe en leer van Jesus van die geskiedenis te bekom. 'The historical Jesus cannot be directly approached except through the medium of the post-Easter faith of his witness. Faith, worship or cult, and preaching set forth and shaped the "forms"' (Dinkler 1975: 685). Daarom moet geloof (en dit sluit ook die geloof van die apostels en die Nuwe Testament in) teruggevoer word tot die innerlike bewussyn van die mens en sy eksistensiële belewing, en nie tot op 'n historiese begronding nie. Vir Bultmann kan die ware kerugma nie histories geverifieer word nie, maar alleen subjektief of eksistensieel. Hierop antwoord Richardson: 'He sets aside the apostolic witness concerning God's action in history in favour of "another Gospel", namely, the proclamation of God's action in the existential transformation of the individual believer' (Richardson 1968: 112). Wat Bultmann hier sê, staan nie op historiese gronde nie, maar op filosofiese gronde - en so kan die empiriese metode van historiese navorsing nie werk nie; dit soek na die vaste vertrekpunt in die werklikheid buite die vrye en onkontroleerbare menslike subjek (bewussyn). Vir Bultmann val die klem in sy hermeneutiek uiteindelik op 'n eksistensiële nuwe verstaan van ons eie historiese situasie as gelowiges vandag. Vir die heilshistoriese teologie val die klem op die Goddelike aksie in die geskiedenis, waarvan die Bybelskrywers berig gee.

Vir die Heilsgeschichte-teologie is dit belangrik om raak te sien dat God gekies het om Hom in Christus te openbaar - nie onmiddellik in die menslike bewussyn nie maar in die geskiedenis. Die geskiedenis is die locus vir die openbaring. Die beriggewing daarvan is in die Skrif. En daarom is die empiries-historiese metode van ondersoek so belangrik, want daar moet nagespeur word wat in die werklikheid van die verlede plaasgevind het. Van Niftrik: 'En ek vertrou ook nie op die kerugma soos Bultmann dit beskryf nie, 'n kerugma wat geen enkele houvas in die feite van die ... geskiedenis het nie' (Van Niftrik 1971:109; my vertaling). 
Wanneer Bultmann die gelowige wil laat eksisteer as gleichsam Entweltlichter, dan wil hy sê dat die mens as ontwêreldlikte wese op niks meer van hierdie wêreld vertrou nie, nie meer die natuur of die geskiedenis nie, maar op God alleen, en so verplaas hy die gelowige in ' $n$ transendente of eskatologiese eksistensie. Onder laasgenoemde word 'n oop toekoms van die mens en sy wêreld verstaan, nou en hier. Dit is vir Bultmann 'n tot deelname kom in jou geloofseksistensie van die nuwe geloofservaring wat die apostels beleef het, wel in mites verskuil, ongeag die verifieerbaarheid van hierdie geloofservaring in die werklikheid van die geskiedenis (vgl Van Niftrik 1971:88-98).

- Dit is belangrik om die bedding te verstaan van waaruit die empiries-historiese metode in die 'Heilsgeschichte' ontwikkel, en daarom verdien twee belangrike stellings van die Vormkritiek-skool van Bultmann, en andere, ons aandag: (i) Die feite oor Jesus van die geskiedenis is alleen toeganklik vir ons deur die geloof van die apostels. (ii) Die taal van godsdiens is ' $n$ denkbeeldige taal, ' $n$ taal van metafore, analogie en simbole. [Die Bybel se verhale is daarom nie letterlik waar nie (Richardson 1968:143145).]

Wat die eerste stelling betref, sê Richardson: Wat hierdie skool nie geslaag het om vas te stel nie, is dat die verhale oor Jesus en die leer van Jesus fiktiewe illustrasies was van die 'Gemeinde-theologie' van die vroeë kerk, wat dan nie van die historiese Jesus af te lei sou wees nie, of baie min, en so het ons net die geloof van die apostels om op peil te trek. Denkbeeldigheid in die geloof van die apostels is nie bewys nie. Tog kan die Vormkritiek-skool ook nie die aanklag ontkom nie, naamlik dat hulle hermeneuties wel godsdiens en geloof bou op die vrye subjektiewe denkbeeldigheid van mense - as laaste grond. Ons geloof en die geloof van die apostels word losgemaak van die historiese feite oor die persoon en werk van Christus. Hierdie eerste hipotese van die Vormkritiek is minder oortuigend as die hipotese dat Jesus self die outeur is van die apostoliese interpretasie van die Ou Testament en van hoe Jesus se Persoon en werk verstaan moet word (Richardson 1968:143). Barth waarsku in sy Kirchliche Dogmatik: Ons moet die Nuwe-Testamentiese tekste toelaat om' te sê wat hulle wil sê en in werklikheid sê. Ons moet daarteen waak om nie 'n ander werklikheid te probeer voorhou as dit wat inderdaad in die Nuwe Testament voorgehou word nie. 'Historiese' kennis in hierdie onbevange benadering is nooit ' $n$ eenvoudige en vanselfsprekende aangeleentheid nie (Barth 1955:167). Richardson sê: 'We must, if we are to be true to the high standard of modern historical research, take the evidence as we find it; we must neither close our eyes to the evidence which exists nor invent fresh evidence which is more ongenial to our own pet theories' (Richardson 1956:60). Indien 'n mens vir die Bybelskrywers, uit ons eie hermeneutiek, wil voorskrywe wat hulle en die vroeë kerk wel ingesien het en wat hulle en die vroeë kerk tog nie werklik waargeneem het nie, is dit 
net so goed as om te peuter met getuienis in ' $n$ hofsaak. Mens moet daarteen waak dat jou eie geloofstwyfel en/of eie geloofsveronderstellings jou nie berowe van 'n objektiewe beoordeling van wat die Bybelskrywers wou berig van wat mense destyds aanskou het, gehoor het, en deurlewe het nie.

Wat die tweede stelling betref, moet gesê word dat die heilsgeskiedenis-teologie die Bybel se proklamasie van die verlossingsdade van God (in Christus) in die geskiedenis deur die apostoliese getuienis objektief as feite vasstel (soos dit daar berig word), en nie historiese gronde vind vir 'n konsekwente mitologiese of metaforiese verklaring nie, en ook nie eenvoudig kan sê dat die Nuwe Testament 'n pre-wetenskaplike manier is om 'n eksistensiële waarheid aan te kondig nie. Die Heilsgeschichte-teologie verstaan die apostoliese kerugma as die getuienis van die werklike getuies wat die dade van God in Christus in die geskiedenis aanskou het. Vir hierdie teologie is daar, in sy objektiewe waarneming, nie 'n skynbaar onoorbrugbare afstand en 'n verskillende weergawe tussen dit wat aanvanklik gebeur het in Christus en dit wat later in die Bybel geskrywe is nie. Menslike simbole en voorstellings in die Bybel word ook nie waargeneem as los van die werklikheid nie. Die menslike voorstellings en simbole (bv van die kruis) interpreteer en kommunikeer wel die gebeure van Christus se dienswerk, kruis en opstanding, maar dit bly nogtans in wese juis gevorm deur die objektiewe gebeure self. Simbole, metafore ensovoorts is bepaal en gevorm deur die objektiewe gebeure self. Die Vormkritiek wil juis loskom van hierdie vormgewing deur die objektiewe gebeure self. Brunner waarsku dat pogings om die Nuwe Testament te suiwer van 'n onaanvaarbare wêreldbeeld - by wyse van ontmitologisering en op basis van Heidegger se eksistensie-filosofie - lei na 'n 'transformasie van die essensie van wat bedoel is in die Christelike kerugma'. Die substansie verander, van byvoorbeeld God se self-openbaring in die geskiedenis na ' $n$ tydlose wese. Wanneer daar gepoog word om op filosofiese wyse die Bybel se simbolisme te interpreteer met ontmitologisering of spiritualisering ensovoorts, dan vind substansiële verandering van die oorspronklike bedoeling plaas en word altyd uitgekom by die 'kategorie van abstraksie'. Die 'Here van alle syn' word vervang met 'syn' op sigself, en die evangelie van Jesus Christus en die apostels word so geïnterpreteer dat 'geen hoop hoegenaamd van 'n ewige toekoms meer oorbly nie' (Brunner 1954:114-120). Terwyl Brunner wys op God se selfopenbaring in Christus in die geskiedenis, beklemtoon hy dat daar in die Nuwe Testament niks van ' $n$ regressie tot onhistoriese tydlose denke' waar te neem is nie. Christus is daarom nie "n mitiese of half-mitiese figuur' nie (Brunner 1964a:49).

Tog mag ons nie skroom om te sê dat die empiries-historiese wetenskap - in aansluiting by wat onder 2.1.4 gesê is - nie in staat is tot 'n onmiddellike of direkte kontak met die kennisobjek nie; trouens, die menslike interpretasie van die werklikheid verdubbel by die historiese wetenskap. Want die historiese navorsers bied ' $n$ weergawe van die weergawe van sy getuienis of dokumentasie oor bepaalde gebeure in die ver- 
lede. Die interpretasie staan egter tog ook weer nie los van die objektiewe gebeure waardeur dit juis gevorm is nie, al is dit dan in dubbele sin. Daar moet bykomend soms rekening gehou word met die waarskynlikheidsfaktor wat ons uit die kwantumfisika leer ken het, en dat dit ons ' $n$ besef gee van ons beperkinge in die navorsing.

Die objekgerigtheid van die empiries-historiese metode dwing die historikus om af te sien van eie subjektiewe veronderstellings ten opsigte van die verlede, en skep 'n bereidheid om die verlede toe te laat om te spreek op die verlede se eie voorwaardes. Hiervoor moet die objektiewe ondersoeker homself oopstel - sodat hy tot verstaan kan kom van die betekenisse wat die verlede self aan dinge en gebeure gee. Die belangrike bly om deur noukeurige waarneming by die $S A A K$, waar dit om gaan, uit te kom. Die werklike saak agter die betekenis is dit wat gevind moet word. Indien die betekenis losgemaak word van die saak, is dit 'n ondersoek na 'n subjektiewe verbeelding teologies gesien: 'n afgod. Vir die vasstelling van objektiewe wetenskaplike feite moet uitgekom word by die saak (gebeure) self. Wat beklemtoon moet word, is dit: Die betekenis is onlosmaaklik deel van die gebeure self. Dodd sê (in Richardson 1968: 130): Die betekenis is eie en inherent aan die gebeure self, en dit geld ook ten opsigte van die Bybel se beriggewing.

Die idees, gewaarwordinge, eksistensiële belewing van mense in die verlede moet as 'n bril gesien word waardeur die historikus na die objektiewe werklikheid van hulle wêreld kyk. Daar moet vir geen oomblik vergeet word dat ons nie self daar was nie, en daarom nie sommer na eietydse veronderstellings kan gryp in 'n poging om te verklaar op 'n wyse wat vir ons meer aanneemlik sou wees nie. Wilhelm Dilthey het beklemtoon dat in relasie tot die historiese objek dit nie soseer die kousale verduideliking is wat tei nie, maar 'n 'verstaan' deur 'n soort identifisering met die objek, en dit is onmisbaar vir die verstaan van historiese gebeure (Brunner 1964:14). Identifiseer dus met die historiese objek, en moenie jouself terugtrek agter die skemas van subjektiewe veronderstellings waardeur jy verkies om na die verlede te kyk nie.

Ontbrekende wetmatigheid is dikwels as kritiek gebruik teen die historiese metode en die wetenskaplikheid daarvan (vgl Dreyer 1974:137, 138). Die kwantum-fisika slaan die bodem van hierdie kritiek uit. Historiese kritiek in die liberale teologie van die $19 \mathrm{e}$ eeu het, op aandrang van die positiviste se fundamentalistiese beskouing van wetenskap, gesê dat die opstanding van Jesus en sy wonders nie waar was nie, omdat wetmatigheid ontbreek vanweë die feit dat dit vandag nie meer gebeur nie. Die punt is dat die objek van die natuurwetenskappe anders is as dié van die historiese wetenskap. Heinrich Riekert het aangetoon dat in die historiese gebeure, wat ondersoek word, die objek eerder ' $n$ unieke individu is, anders as by die naturuetenskappe waar universele wette 'n bepalende rol speel by objekte en kousaliteit sterk op die voorgrond tree. Tog 
is daar ook 'n mate van 'n herhalende oorsaaklikheid in die objektiewe wêreld van die geskiedenis: Die opstanding van Jesus Christus is die rede vir die opkoms van die Christelike geloof, die kerk, en die belydenis dat Jesus die Here is, God is. En hierdie oorsaaklikheid herhaal hom in die geskiedenis tot vandag toe, elke dag.

Die empiries-historiese wetenskap is ook baie skepties ten opsigte van die subjektiewe rekonstruksie van 'n sosiologiese model waarmee na die verlede gekyk word om dit daarmee te interpreteer (vgl Van Aarde 1993:942-959). Die probleem is dat so 'n model uiteindelik baie subjektief is. Die model is wel gevorm uit tendense in die verlede wat teruggevind kan word, maar wanneer die model gebruik word om 'n bepaalde objek te beoordeel, word daar nie beoordeel vanuit noukeurige waarneming van die spesifieke objek self nie, maar vanuit veronderstellings wat deur die subjektiewe bewussyn saamgestel is. Die objektiewe vertrekpunt bestaan dus nie; die werklike objek het nie die geleentheid gehad om homself te wees nie - ons het dan die werklike objek se aanbieding van homself subjektief, anders, ingekleur. Dan het ons nie meer wetenskaplike feite nie. Anders gesê: Daar kan nie vanuit 'n spesifieke sosiologiese omgewing oorsake vasgestel word en dan vanuit hierdie oorsake 'n mens geprojekteer word nie, en dan veronderstel word dat ander mense van daardie omgewing noodwendig ook so sal lyk soos die geprojekteerde mensemodel nie. Alle mense is nie sonder meer produkte van hulle omstandighede nie, en dit boonop identies met die ander produkte van omstandighede. Die mens is individueel baie meer uniek homself. Veronderstellings (soos 'n sosiologiese model) is nie die oorsprong of grond vir die werklikheid nie, maar die werklikheid is wel die grond waaruit ons 'n beoordeling maak. Dis duidelik baie gevaarlik om Jesus Christus vanuit 'n sosiologiese model te probeer beoordeel.

Dat die gebeure van Jesus Christus se kruis en opstanding nie plaasgevind het nie, sal wetenskaplik alleen bewys kan word indien ander gebeure van daardie tyd gevind kan word wat dit kan weerlê - maar nie vanuit subjektiewe veronderstellings van ons tyd nie. Sulke gebeure is nog nie gevind nie.

Die teologie en die empiries-historiese wetenskap ondersoek die Skrif op 'n objektiewe wyse

in 'n ewige soeke na 'n groter gebeure daaragter - die historiese Jesus, en die Woord van God. Die beriggewing en dokumentasie van die Skrif is, soos historiese dokumentasie in die algemeen, die naaste wat ons aan die werklikheid van die verlede kan kom. Teologies beteken dit dat ons nooit 'n greep op God en sy Woord kan kry nie. God beskik alleen oor sy Woord. Die teologie is ewig op soek na God se Woord. Die Skrif is die naaste wat ons aan die Woord van God en die gebeure van Jesus 
Christus kan kom. Daarby beteken dit nog altyd dat ons geloof (in die God in ons) en ons teologisering nie op eie bene van menslike willekeur moet probeer staan nie, maar gesubstansieer moet word uit die werklikheid van die Christusgebeure, 'n objektiewe werklikheid buite die menslike subjek, en ons het menslik gesproke alleen die dokumentasie van die Skrif om ons daarin te help.

(Labuschagne 1995:1190)

Die Heilsgeschichte-teologie behou steeds 'n noue band tussen die sekerheid van die geobjektiveerde kennis en die geloofsoortuiging wat die mens van God se Gees ontvang in eksistensiële gewaarwording. Die geloofsoortuiging is wel nie sonder die vormgewing van die oorsaaklike werklike gebeure nie. Van Niftrik: 'Dit lyk vir my Bybels om die subjek afhanklik te maak van die objek, wat hom deur sy "testimonium" met egte gesag aan die subjek oplê ...' (Van Niftrik 1971:54; my vertaling).

\section{DIE EMPIRIESE GESKIEDENISBESKOUING MET TOEPASSING OP DIE OPSTANDING VAN JESUS CHRISTUS}

Die vroeë kerkvader, Athanasius (295-373 n C), het met groot klem die verband aangetoon tussen die triniteitsleer en die soteriologie. In hierdie uiteensettings van hom het hy nie moeg geword om oor en oor te sê dat subordinasie van die Seun aan die Vader, soos die Arianisme dit geleer het, gelei het na 'n gebrek aan KENNIS van God. Athanasius sê: As die Seun nie volledig en waaragtig God is nie, kan die Seun ons nie leer van God en God aan ons openbaar nie. Die Godheid van die Seun is identies met die Godheid van die Vader (Schulze 1978:60,61).

So het Athanasius die kerk reeds vroeg geleer van die mens se onvermoë om uit homself tot kennis van God te kom; net God self kan ons leer van God. Wanneer die natuurwetenskappe en aanverwante tegnologie vir ons so baie wonderlike dinge van die skepping ontsluit, dan stamel ons in verwondering: God! - God het dit alles gemaak. Dis ons konklusie, en ons gewaarwording, maar wat weet ons tog van God? En hoe geweldig groot is die skepping nie: bestaande uit sonnestelsels op sonnestelsels, met afstande van miljoene ligjare uit mekaar. Geneem die feit dat 'n ligstraal teen die spoed van $300000 \mathrm{~km}$ per sekonde beweeg, is die afstand oor een jaar wat teen dié spoed afgelê word, enorm. Wat dan nog van afstande van miljoene ligjare! Maar veronderstel dat die mens, met sy tegnologie, in staat is om teen $300000 \mathrm{~km}$ per sekonde te beweeg (sonder om self lig te word), dan sou 'n mens nog miljoene jare moet leef om te gaan kyk wat die Skepper gemaak het in die heelal. Het hierdie heelal 'n grens iewers? Hou alles iewers op? As daar 'n grens is, wat is anderkant die grens? Niks? 
Wat is niks? - neem niks ruimte in? Of is die skepping dalk oneindig? Maar wat is 'oneindig? Alles vrae wat die vermoëns van die mens totaal te bowe gaan. Nou - hoe praat ' $n$ mens met dié Een wat dit alles gemaak het? Hoe kommunikeer 'n beperkte menslike wese met die Intellek en die Verstand - God - wat dit alles gemaak het? En sou Hy mensetaal praat? Hoe kom 'n mens op daardie geweldige hoë vlak - om met God te praat? Hoe kom 'n mens tot kennis van God? Hoe bereik 'n mens God? Wanneer ons wetenskaplik dink en redeneer, word ons gedwing, deur die wêreld en die mens wat ons aanskou, om te begin deur te sê: Uit homself weet die mens van God net een ding, an jy het baie ver gevorder wanneer jy dit ontdek het, en dis 'n ronde nul niks! Die mens weet van God alleen dit: Niks. Indien God nie self die inisiatief neem, en die hemele oopbreek, en na ons vlak toe afdaal nie, sal ons ewig van Hom net niks weet. Hoe eienaardig is dit dat daar by alle volke en mense wel 'n bewussyn van God is, en ons kan dit objektief waarneem, maar wanneer ons vra na inhoud, dan is die antwoord altyd: daar is niks (vanuit die mens self).

Tog is die geskiedenis van die mensdom deurgaans vol voorbeelde van filosofiese en teologiese pogings van die mens om vanuit die mens self te soek na God en te soek na kennis van God - en dan uiteindelik daardie kennis suiwer vanuit die menslike bewussyn te veronderstel. Dit beteken daar word uitgegaan vanuit die beginsel van subjektiwiteit. Subjektiwiteit is daardie beginsel waarvolgens die finale of laaste grond van ons kennis nie buite die mens te vinde is nie, maar in die mens. Subjektiwiteit vind ons in die twee-wêreldebeskouing vanaf Plato (427-347 v C) en Aristoteles (384322 v C) tot by Descartes (1596-1650), Leibniz (1646-1716) en Wolff (1679-1754) by wie dit sy afloop bereik. Die twee-wêreldebeskouing onderskei tussen die wêreld van die sigbare konkrete dinge en die metafisiese wêreld van die ideële: laasgenoemde waaruit alles wat bestaan, op een of ander wyse suiwer rasioneel geken word deur die menslike bewussyn. God en godsdiens maak deel uit van die metafisiese wêreld (Labuschagne 1987:120-145). Na Immanuel Kant (1724-1804) is die beskouing van 'n aprioriese vertrekpunt in die kennisproses, en so ook die twee-wêreldebeskouing, vir goed aan skerwe; wetenskaplike kennis kan voortaan alleen sy vertrekpunt neem in die objektiewe werklikheid buite en onafhanklik van die menslike bewussyn.

Teenoor die beginsel van subjektiwiteit het Karl Barth nog altyd die standpunt van objektiwiteit in die teologie gestel, naamlik dat die laaste grond vir ons kennis onafhanklik, buite die menslike bewussyn, in 'n selfstandige werklikheid te vind is. Karl Barth leer in sy Kirchliche Dogmatik (Band I) dat God vir die mens die Ander is, dat Hy in Goddelike objektiwiteit en Gegenständlichkeit teenoor die mens staan, en dat menslike geloof daarom 'n daad van erkenning van die Ander is, en so het die lewe van die mens (sonder om op te hou om sigself bepalende lewe van hierdie mens te wees) sy sentrum, sy 'Woher' (sy waarvandaan), buite homself gevind in die God wat Hom in Christus geopenbaar het, en deur die Heilige Gees erkenning van Hom by die mens 
daargestel het (Van Niftrik 1971:109). Barth sê ook: 'wat liefde, vertroue en gehoorsaamheid teenoor God is - dit alles volg uit die feit dat Hy Hy is, objek op die menslike niveau soos ander objekte - dat Hy Hom in relasie tot die mens stel en die mens in relasie tot Hom .... Geloof beteken in die Bybel: die oopmaking van die menslike subjektiwiteit deur die objektiwiteit van die Goddelike $H y$ en vir hierdie objektiwiteit, en dan ook in en deur hierdie oopmaking van die subjektiwiteit 'n nuwe fundering en 'n nuwe bepaling van die menslike subjektiwiteit' (Van Niftrik 1971:116). Vir Barth het die objektiwiteit van God en God se 'Gegenständlichkeit' niks te make met 'n filosofiese realisme of objektiwisme nie (Van Niftrik 1971:105). Die objektiwiteit van God is tegelyk altyd die subjektiwiteit van God (Van Niftrik 1971:105). Die selfstandigheid van God kan nooit binne die perke van menslike mag gebring word nie. God behou altyd die sowereine inisiatief.

Subjektiwiteit as laaste grond in die teologie het nie sonder reaksie by die wêreld verbygegaan nie. Ludwig Feuerbach (1804-1872) kan nie verkwalik word nie, wanneer hy hierdie pogings van die mens, om uit homself (uit sy eie bewussyn) tot kennis van God te kom, waarneem en dan sê: 'alle teologie is psigologie', en: die moderne Christendom sien nie meer raak nie dat die mens uit homself die idee van God produseer, om sy begeertes en verlangens op daardie God te kan projekteer. Schleiermacher het die godsdiensgevoel gedefinieer as 'n gevoel van afhanklikheid, maar laat dit onuitgemaak vanwaar hierdie gevoel sy objek (van God en godsdiens) verkry. Feuerbach het dit sy taak gemaak om vervolgens aan te toon dat die menslike gevoel self sy objek produseer (kyk Höffding 1955:272-282; Störig 1974:116, 117). Die konsekwensies van denke, soos by Schleiermacher, is inderdaad dit wat Feuerbach daarvan maak: Die mens skep sy eie God en godsdiens, en projekteer dan daarin dinge wat vir hom baie belangrik is. Dit is inderdaad ook die konsekwensies te trek uit die beskouings van 20e eeuse teoloë wat die vertrekpunt neem in die beginsel van subjektiwiteit, insluitende die Vormkritiek van Bultmann en andere. By Bultmann wat uitgaan van die beginsel van subjektiwiteit word alleen oor God gepraat vanuit die eksistensiële belewing van die mens, God word geabsorbeer in die ervaring van die mens, en dit geld van die NuweTestamentiese skrywer sowel as die Christen van vandag, hier en nou. Maar ander stel dit skerper en meer direk dat God verwerklik word deur die toedoen van die mens, byvoorbeeld Mezger.

Manfred Mezger sê: 'God is geen syn nie, maar 'n gebeure; geen begrip, maar 'n gebeure. Wie sonder 'n gebeure, sonder 'n gebeure tussen mens en mens in hierdie wêreld van ons, or God praat, sê niks ...' (kyk Van Niftrik 1971:111). In hierdie siening word God dus deur die mens verwerklik deur dit wat die mens doen in die relasie van mens tot mens, en ook in die geheel van die wêreldgeskiedenis. Daar is egter niemand anders as die mens self wat die subjek van die wêreldgebeure en geskiedenis is nie. God moet deur die mens verwerklik word in dinge soos maatskappykritiek en 
politieke en sosiale aktiwiteit (Van Niftrik 1971:111, 112, 126). Thielicke waarsku dat in hierdie soort teologieë (soos by Mezger) die ervaarbaarheid van God met die syn van God geïdentifiseer word (kyk Van Niftrik 1971:113). Mezger kan ook so geantwoord word: God sou in werklikheid ophou om te bestaan, in die besonder ophou om vir ons te bestaan, wanneer Hy geheel en al prysgegee word aan die mens en aan wat die mens van Hom sou maak. Die ware God sal nie daar wees nie. By Herbert Braun hou God en Christus op om 'n 'Gegenstand' te wees, en gaan Hy op in die menslike eksistering, gaan Hy op in die menslike 'ek mag' en 'ek moet' in die kader van medemenslikheid - die mens in sy medemenslikheid impliseer God dan so (kyk Van Niftrik 1971:110, 111). Van Niftrik sê tereg dat ons in 'n tyd lewe waarin 'teologie tot antropologie' word, en die mens homself so mondig ag dat "hy in eie krag God kan "verwerklik" (Van Niftrik 1971:132).

God se volstrekte onafhanklikheid gaan verlore in die uitgangspunt van menslike subjektiwiteit. Wanneer ons die persoon en werk van Christus nie meer in objektiewe historiese gebeure, teenoor ons, kan waarneem nie, beteken dit dat ons die volstrekte onafhanklikheid ('Gegenständlichkeit') van God teenoor die mens nie meer begryp nie, en dan beteken ons spreke oor God dat ons God in die subjektiewe eksistensiële belewing van die mens laat opgaan en die ware God sodoende prysgee vir 'n god wat deur die mens gemaak is. Maar 'n god wat deur die mens gemaak is, bestaan nie werklik nie. So verdwyn God in die onbereikbare en die onkenbare, in die niksheid wat vir ons oorbly. Ons moet daarom elke absorbering van God in die ervaring van die mens, in die eksistensiële belewing van die mens, op grond van die Bybel se beriggewing, bestry; God is die 'onophefbare' Andere, sê Barth, wat die menslike syn, gevoel, ken, wil en doen ver te bowe gaan (kyk Van Niftrik 1971:108).

Dit alles bring ons terug by Athanasius en ons soeke na kennis van God. Wat nou duidelik geword het, is dat in ons soeke na kennis van God, daar nie suiwer vanuit die menslike bewussyn 'n pad na God is nie - so is daar alleen 'n doodloopstraat. So is daar alleen niksheid. Wanneer die mens, in sy ontoereikendheid en afhanklikheid, vanuit sy eie bewussyn van God en godsdiens 'n neurotiese projeksie maak, kom die mens alleen uit by sy eie afgod. Daardie god bestaan nie. Daar bestaan nie ' $n$ pad van die mens na God nie. Daar bestaan alleen 'n pad wat God, in Christus, na die mens gebaan het. In Jesus Christus het God die inisiatief geneem en die hemele oopgebreek en neergedaal tot op ons vlak. Daarom het Hy in Christus ' $n$ menslike gestalte aangeneem, en praat God, in menslike gestalte, met ons mensetaal. Eers wanneer God met ons mensetaal praat en ons in menslike gestalte ontmoet, ons op ons vlak kom ontmoet, kan ons iets verstaan en weet van God - kennis van God ontvang. Net God kan as God praat, ons iets sê van God, ons kennis van God meedeel - dit kan geen mens voorgee om namens God te doen nie. Dat Jesus Christus wat volledig mens geword het, tegelyk waaragtige God is, is gevolglik oneindig belangrik om te weet vir ons 
soeke na God en ons soeke na kennis van God. En nou is dit vir die eerste maal vir die mensdom in die opstanding van Jesus Christus duidelik dat hierdie man wat dood was en weer lewe, werklik God is, want 'n mens kan nie homself lewendig maak as hy eers gesterwe het nie. Uit die historiese opstanding van Jesus Christus (wat deur meer as 500 mense aanskou is, berig Paulus in 1 Kor 15) weet ons vir seker soos 'n Tomas van ouds (Joh 20:28) dat Jesus 'God' en 'Here' is (vgl ook Rom 1:4). Nou weet ons dat ons van Jesus, die Here, kennis van God ontvang - en God in Hom ontmoet. Sonder die opstanding van Jesus Christus, val alles, in ons soeke na God en kennis van God, geheel plat - bly daar net niks oor. Sonder die opstanding van Jesus Christus moet ons ook soos Paulus sê: 'En as Christus nie opgewek is nie, is ons prediking sonder inhoud en julle geloof ook sonder inhoud' (1 Kor 15:14). In ons soeke na God, en kennis van God, het dit God behaag om in een kort helderskynende oomblik in die geskiedenis Hom in Christus aan ons bekend te maak. Sonder dit, het ons vanuit die objektiewe wetenskap niks. Die hele Skrif vind sy waarheid nou in relasie tot hierdie Christus-gebeure, en die betekenis van alles in die wêreld is daardeur geraak.

Die opstanding van Jesus Christus (en daarmee saam Christus se hemelvaart) is daarom begryplik vir Karl Barth so belangrik dat hy sê: 'Wir nannten Auferstehung und Himmelfahrt im Unterschied $\mathrm{zu}$ allem Vorangegangenen das dieses abschließende und zusammenfassende, das entscheidende und eindeutige Offenbarungsereignis'. ('Die opstanding en hemelvaart is, in onderskeiding van alles voorafgaande, deur ons aangedui as die hierdie afsluitende en samevattende, die beslissende en die onmiskenbare openbaringsgebeurtenis' - my vertaling) (Barth 1955:156, 157). So sê Barth dan van die opstanding van Jesus Christus, teenoor Bultmann en die Vormkritiek: 'Om hierdie rede moet ons eenvoudig Nee sê vir Bultmann se "ontmitologisering" van die Nuwe Testament. Die "opstanding van Jesus Christus" beteken die opstanding van hierdie een persoon in onderskeiding van alle ander, en so as 'n gebeure in ruimte en tyd net soos die gebeure van Golgota. As dit nie dit beteken nie, word hierdie gebeure gereduseer tot ' $n$ nuwe determinering van die menslike eksistensie, tot die ontwaking van geloof in die eerste dissipels. Dan is daar geen Christus vir ons en oor ons om die bestaan van Christus in ons te substansieer nie. Dan word die paasboodskap as sulks omvergewerp en tot niks gemaak' (Barth 1964:75, 76; my vertaling). En ook: 'As Bultmann maar net wou sê dat ons hier te doen het met geskiedenis (nie mite nie!) in die vorm van sage of legende, kon daar geen beswaar teen hom gewees het nie. Want dit is nie moontlik om die ware historiese karakter van die beriggewing in hierdie vorm te ontken nie .... Die Bybel bevat talle sages en legendes, maar dit sou vals wees om uit hierdie feit tot die konklusie te kom dat hulle nie uitdrukking van werklike gebeurtenisse is nie. En so ook hier is dit die bedoeling om ware geskiedenis te wees .... Die regmatige volgorde hier is paasgebeure - paasboodskap (sage!) - paasgeloof (die teenoorstaande ervaring van die ervaring van die kruis). Wie ook al begin by die 
paasgeloof met die oog daarop om dit die inhoud van die paasboodskap te maak en uiteindelik die paasgebeure prys te gee en te laat wegval - sy redenering oor hierdie onderwerp is vervelig en sekerlik nie geldig nie' (Barth 1964:76; my vertaling). Uitdruklik sê Barth van Christus se opstanding: 'Ons moet nie die opstanding in 'n geestelike gebeure omwissel nie' (Barth 1960:123; my vertaling).

Die opstanding van Jesus Christus (en so ook sy hemelvaart), sê Barth, leer ons dat Jesus God is: 'Gewis word Hy en is Hy in sy opstanding en hemelvaart ook as Seun van God geopenbaar, maar nou juis in die krag en die heerlikheid van sy eenheid met die mens Jesus van Nasaret .... En om die openbaring van hierdie mens se verhoging en hoogheid in sy eenheid met die Seun van God het dit gegaan en gaan dit in Jesus Christus se opstanding en hemelvaart. Wat hier openbaar word, is dat presies hierdie mens, in sy identiteit met die Seun van God, die Here was' (Barth 1955:168; my vertaling). 'En juis in hierdie voleinding van sy werk het sy syn in sy opstanding en hemelvaart openbaar geword' (Barth 1955:158; my vertaling). Van die opstanding van Jesus sê hy: 'Es ist das konkret geschichtliche Ereignis der Selbstkundgebung Jesu nach seinem Tode' ('Dit is die konkrete historiese gebeure van die selfbekendmaking van Jesus na sy dood') (Barth 1955:163; my vertaling). En oor kennis van God vervolg hy dan: 'Als solcher, in diesem Ereignis, wird er als der, der er ist, und wird in ihm der Wille und die Tat Gottes erkannt' ('As sulks, in hierdie gebeurtenis, word Hy as die Een wat Hy is, bekend gemaak, en word in Hom die wil en die daad van God geken') (Barth 1955:163; my vertaling).

Oor kennis van God in die selfopenbaring van God in die opgestane Jesus sê Barth:

Dit maak 'n menslike kennis wakker en begrond dit, maar dan alleen as 'n begrip wat bestaan in ' $n$ begryp van die heilig onbegryplike. Ons verstaan onder sy heilige onbegryplikheid, en so dan onder sy majesteit, daardie nuutheid, andersheid, ja vreemdheid, wat wesenlik, noodwendig, eiendomlik is aan Hom as die gebeure van die openbaring van die verborge teenwoordigheid en handeling van God in die vlees, en so van die wil en daad van God midde in 'n van Hom vervreemde wêreld en mensdom. "Dit is die Here" (Joh 21:7), wat reeds in die verborgenheid van sy knegskap die Here was en nou as die Here uit hierdie verborgenheid na buite tree: die Heer van die verbond, wat ook die Heer van die wêreld en die mens is. Hy is die Heer, as Heer openbaar Hy Hom ook: as sodanig vir alle menslike waarneming en denke ontoeganklik, maar tog ook die Heer van menslike waarnemings- en denkvermoëns: nie gebonde aan hulle grense, vry om Hom aan die mens en binne hulle grense kenbaar te maak .... Dit is die lig van hierdie gebeure, die lig van die 
opstanding en die hemelvaart, in welke kennis ontstaan: kennis van Jesus Christus, kennis van die wil en daad van God. In enige ander lig, in 'n ander toeganklikheid as deur sy eie toegang verskafde tot kennis kom, sou Hy nie die Here wees nie. Kennis van die Heer is kennis deur Hom as Heer in die daad van sy majesteit gegee.'

(Barth 1955:163, 164; my vertaling)

Barth vervolg:

Omdat en terwyl die openbaringsgebeure aan die majesteit van die wil en daad van God deel het, ... het dit noodwendig die karakter van 'n wonder, impliseer sy gebeure 'n element waarvolgens dit uit alle analogieë van ander gebeure uitval, en waarvolgens dit as objek van menslike waarneming onverklaarbaar is en as objek van menslike denke nie herhaalbaar is nie, wat, teenoor menslike waarneming en menslike denke en sodoende menslike kennis, juis alleen in die vasstelling van sy werklikheid kan bestaan.'

(Barth 1955:164; my vertaling)

Barth wys daarop dat daar wel ook ander dinge in die wêreld is wat tot 'n sekere mate, of selfs totaal, ongewoon is wat nie verstaan en verduidelik kan word in terme van gewone waarneming en gewone kennis nie, en wat tog nie God se openbaring is nie en ook nie daaraan gelyk gestel kan word nie; God se openbaring bied kennis van Jesus Christus as God, en daarmee die begronding van alle kennis oor God, en dit impliseer altyd 'n wonder van God - dat dit alles vir 'n mens kenbaar gemaak kan word (Barth 1955:165). Treffend is hierdie sin van Barth:

Opstanding en hemelvaart is hierdie eens en vir altyd gebeure en voldoende openbaringsgebeurtenis: die gebeurtenis van sy selfbekendmaking en as sodanig die gebeure waarin die basis vir kennis van Jesus Christus, waarna ons juis hier vra, gelê word en gelê is: die objektiewe kennisbegronding waarin alle subjektiewe kennis van Jesus Christus uitsluitlik sy oorsprong kan hê, deur die getuienis van die Heilige Gees so is dit met die kennis van die dissipels, die eerste gemeente, die latere kerk en sy teologie, ons eie kennis - alleen van hieruit, wanneer dit hieruit afkomstig is, kan dit 'n onvoorwaardelike en betroubare kennis wees, omdat dit uitdruklik in sy objektiewe werklikheid self begrond is.

(Barth 1955:159; my vertaling) 
Daar kan ook 'geen openbaring van God essensieel verskillend van die openbaring in Christus wees nie' (Cullmann 1963:321; my vertaling). In kort: Kennis word alleen in die objektiewe werklikheid self begrond. So is ons kennis van God alleen in die objektiewe werklikheid begrond - in en deur Jesus Christus wat mens geword het, en so sigbaar geword het, en sy Godheid in sy liggaamlike opstanding uit die dood openbaar het.

Vir die empiries-historiese wetenskap is daar sonder die liggaamlike opstanding van Christus geen openbaring van God - waar en seker - en sonder dit is daar geen kennis van God nie. Daar is nie 'n pad van die mens na God toe nie; daar is alleen 'n pad van God na die mens toe - in Christus Jesus, wat opgestaan het uit die dood en wat die Skrif sy volle betekenis kom gee het (Matt 5:17-20). Vir 'n vergeesteliking van gebeure is daar geen ruimte by Barth nie. Die opstanding en hemelvaart van Jesus Christus is vir Barth iets wat geskied, soos die hele voorafgaande geskiedenis van Jesus, in die wêreld ('als auch es ein innerweltliches'), en dit wil sê binne ons ruimte en tyd ('im Raum und in der Zeit'), en dis beslis nie iets wat eenvoudig vergeestelik moet word nie, want dit is stoflike gebeure wat in die liggaam, dus fisies en fisies sigbaar ('auch körperlich geschehenes') plaasgevind het (Barth 1955:160). Hy vervolg oor opstanding en hemelvaart: 'Dit is 'n gebeure met 'n verloop, soos die paasberiggewing wat nie misverstaan kan word nie en met nadruk sê, soos dit dan verder ook in 1 Johannes 1 onderstreep word, van met die oë gesien, met die ore gehoor, met die hande aangeraak .... Dit is - nie "histories" in ons sin nie - maar as geskiedenis gesitueerd en gekarakteriseerd soos ander gebeure onder mense plaasvind, en deur hulle beleef is en daarna deur hulle betuig is' (Barth 1955:160; my vertaling).

Kennis van God - nie los te sien van opstanding nie - hou vir Barth ook weer verband met die ontstaan van die kerk: Die doel van die werk van Jesus Christus, wat eens en vir altyd gebeur het, is die grondslag van die kerk deur die kennis, toevertrou aan die getuies van sy opstanding, van die almag van God en die genade van God wat een en dieselfde ding is en wat aktief en sigbaar in Hom is ...' (Barth 1960:124; my vertaling). Richardson stel dit so: 'The historical evidence is that the Church came into existence because of the apostles' conviction that Jesus was risen, and we should note that there is no possible alternative interpretation of the evidence that can be called historical' (Richardson 1956:59). Die Christendom sou nie oorlewe het sonder die historiese werklikheid van die opgestane Here, Jesus Christus nie. Herbert Butterfield sê:

Christianity could hardly have persisted in its traditional form if scholarship had succeeded in demonstrating that Christ Himself should be regarded as a mythical figure ... for it is the characteristic of an historical 
religion to be rooted in earthiness and to have a vivid apprehension of material things. One of the things in history which reveal a strange and powerful insight and seem to point to a providential order, is the extraordinary firmness shown in this matter by the Church in the early centuries, which would have no tampering with the flesh of Christ, no conjuring tricks and optical illusions .... Some of the bewildering controversies in early Church history become more manageable to our minds if we realise that the central object of the Church was to maintain the full humanity as well as the full divinity of Christ.

(Butterfield 1954: 128, 129)

\section{SLOTOPMERKINGS}

Die wêreld van Barth, en die 'Heilsgeschichte'-tradisie aan die een kant, en die wêreld van Bultmann, en die 'Formkritiek'-tradisie aan die ander kant, gaan nie soseer uiteen oor die metode van objektiewe histories-wetenskaplike navorsing nie, maar wel oor die evaluering en verklaring van die feite en gebeure waaroor berig gegee word: dit wil sê oor die hermeneutiek. In die hermeneutiek volg eersgenoemde skool nog steeds die objektiewe uitgangspunt, terwyl Bultmann en die Vormkritiek-skool nou, onder die invloed van die eksistensie-filosofie, ' $n$ ander uitgangspunt volg: die beginsel van subjektiwiteit. Vir Bultmann kan die ware kerugma alleen subjektief, of eksistensieel, werklikheid word, en gaan dit om 'n subjektiewe tot deelname kom van die nuwe geloofservaring wat die apostels belewe het - hoewel daardie geloofservaring van die apostels en die vroeë kerk, in mites verskuil gelê het. Vir Barth gaan dit om geloofsbeslissing en geloofsbelewing wat in die objektiewe werklikheid van die geskiedenis veranker word en deur die Heilige Gees tot oortuiging word.

Empiries-historiese navorsing van die Bybel se tekste en aanverwante dokumentasie van die Bybel se tyd, sowel as die samelewing en kultuur van daardie tyd, asook die geskiedenis en geskrifte van die vroeë kerk, moet bevorder word om ons 'n steeds duideliker beeld van die objektiewe werklikheid van daardie tyd te bied.

Die historikus sal daarop ingestel moet bly om steeds die doeltreffendheid en skerpte van sy metodiek te verbeter - om waarheid en sekerheid te bevorder. Wetenskaplike metodiek kan nie genoeg beklemtoon word nie. Soms moet byvoorbeeld gewaak word teen te vinnige aansprake: ons mag voorbeelde vind van skynbare 'teenspraak' in die verskillende beriggewing van die opstanding van Christus, dan moet onthou word dat ons dink en werk 2000 jaar na die gebeure - en ons het nie al die verskillende aspekte van die gebeure in ons hande nie. Dit is soms goed om met wiskundige klaarheid ook na die werklikheid te kyk, en dan versigtiger te evalueer en te 
verklaar: In 'n vierkant, met hoeke $A, B, C$ en $D$, en waarvan die 4 sye ewe lank is, lê daar 100 ewegroot blokke. Wanneer iemand nou 90 van daardie blokke wegneem sodat slegs vier in hoek $\mathrm{A}$ en ses in hoek $\mathrm{C}$ oorbly, gaan dit lyk of die vier blokke in hoek $\mathrm{A}$ en die ses blokke in hoek $\mathrm{C}$ niks met mekaar te doen het nie, want hulle is geheel los van mekaar, en trouens, hulle staan teenoor mekaar. So is dit in historiese navorsing: omdat jy nie al die gegewens het nie, of nog te min gegewens versamel het, lyk dit soms of dinge in teenspraak tot mekaar kan staan. Die historikus is dan egter baie versigtig en verklaar dan alleen wat hy werklik duidelik kan sien - byvoorbeeld uit die beriggewing van Jesus se opstanding is dit duidelik dat Hy liggaamlik opgestaan het en dat baie mense Hom gesien het, hoewel ons nog nie al die verbande van die gegewens tot mekaar kan verklaar nie (ons onthou dan die les wat ons geleer het uit die wiskundige vierkant).

Die studie van die vroeë kerkvaders is net so van groot belang - omdat hulle 17 of 18 , of meer eeue, nader aan die werklikheid van die Nuwe-Testamentiese tyd as ons gelewe het. En dit word veral soms onderskat. Indien ons in 'n totaal ander koers as hulle wil beweeg, sal dit, histories-wetenskaplik, ernstig bevraagteken moet word dit is as ons wil vashou aan die werklikheid van die Nuwe-Testamentiese wêreld.

Ons sou nog veel meer kon sê oor wetenskaplike metodiek, en dis belangrik. Tog vergeet ons geen oomblik dat dit alles tog uiteindelik gaan om die bestaan van God, dat ons onwrikbaar glo in God, op grond van die God wat Homself bekend gemaak het in historiese gebeure in en deur Jesus Christus, en op grond van Christus se Heilige Gees wat ons eksistensieel aangeraak het. 'Die historiese Jesus Christus is slegs 'n nuttelose herinnering as Hy nie die lewende Here teenwoordig by ons is nie, wat aan sy dissipels belowe het: "Ek bly altyd by julle" (Brunner 1964a:54, 55). Ons vergeet ook vir geen oomblik dat in wetenskaplike ondersoek ons slegs so ver kan gaan as wat God ons toelaat in sy selfbekendmaking. God kan nie beperk word, vasgegryp word, deur die denke van mense, of deur kerklike dogmas, die liturgie van die erediens, of selfs die woorde van die Bybel nie. Alleen in geloof waag ons dit in ons ontoereikendheid om iets van God te sê - maar dan nie soos ons of enige mens wil nie, maar soos Hy Hom self objektief (los van ons!) bekend gemaak het. Bestaan God dan wel? Ons antwoord in die woorde van André Frossard: 'Jy kan my nog meer vertel maar ... God bestaan, want ek het Hom ontmoet'. En wel in en deur Jesus Christus wat na my toe gekom het (Van Niftrik 1971:139; my vertaling), Hy wat sy kerk kragtens sy belofte deur die eeue heen bewaar en waarvan die geskiedenis getuig (vgl Matt 16:18).

\section{Literatuurverwysings}

Barth, K 1955. Die Kirchliche Dogmatik, Vierter Band: Die Lehre von der Versohnung. Zweiter Teil. Zürich: Evangelischer Verlag AG.

1960. Dogmatics in outline, tr by G T Thomson. London: SCM. 
Barth, K 1964. The Heidelberg Catechism for today, tr by S C Guthrie. London: Epworth Press.

Bernstein, J 1976. Einstein. Glasgow: Collins.

Brunner, E 1954. Eternal hope, tr by Harold Knight. Philadelphia: Westminster Press.

- 1964. Truth as encounter, tr by A W Loos \& D Cairns. Philadelphia: Westminster Press.

- 1964a. The Word of God and modern man, tr by D Cairns. Richmond: John Knox Press.

Bullock, A \& Stallybrass, O 1977. The Fontana Dictionary of modern thought. London: Collins.

Butterfield, H 1954. Christianity and history. London: G Bell \& Sons.

Cullmann, O 1963. The Christology of the New Testament, tr by S C Guthrie \& C A M Hall. London: SCM.

De Vleeschauwer, H J 1952. Handleiding by die studie van die Logika en die Kennisleer. Pretoria: Uitgewery J J Moreau \& Kie.

Dinkler, E 1975. Form Criticism of the New Testament. Hong Kong: Thomas Nelson \& Sons. (Peake's Commentary on the Bible.)

Dreyer, P S 1974. Inleiding tot die filosofie van die geskiedenis. Pretoria: HAUM.

Höffding, H 1955. A history of modern philosophy, philosophy, Vol II, tr B E Meyer.

New York: Dover Publications.

Kant, I 1956. Kritik der Reinen Vernunft. Hamburg: Felix Meiner Verlag.

Kuypers, K 1966. Over Kant en zijn betekenis voor onze tijd. Baarn: Het Wereldvenster.

Labuschagne, J P 1987. Die historiese konteks van 20ste eeuse samelewingsteologieë. DD-proefskrif, Universiteit van Pretoria.

- 1995. Die houding en betrokkenheid van die kerk in 'n veranderende SuidAfrika. HTS 51/4, 1187-1216.

Richardson, A 1956. Science, history and faith. London: Oxford University Press. - 1968. The Bible in the age of science. London: SCM.

Schulze, L F 1978. Geloof deur die eeue. Pretoria: NG Kerkboekhandel.

Störig, H J 1974. Geschiedenis van de Filosofie, Volume II, vertaald door P Brommer \& J K van den Brink. Utrecht: Uitgeverij Het Spectrum.

Van Aarde, A G 1993. Recent developments in South African Jesus research: From Willem Vorster to Andries van Aarde. HTS 49/4, 942-962.

Van Huyssteen, J Wentzel 1996 . The shaping of rationality in science and religion. HTS 52/1, 105-129.

Van Niftrik, G C 1971. Het bestaan van God in de kentering van deze tijd. Den Haag: J N Voorhoeve. 